\title{
Neuronal Cav3 channelopathies: recent progress and perspectives
}

\author{
Philippe Lory ${ }^{1,2}$ (D) Sophie Nicole ${ }^{1,2} \cdot$ Arnaud Monteil $^{1,2}$
}

Received: 8 June 2020 / Revised: 8 June 2020 / Accepted: 26 June 2020 / Published online: 7 July 2020

(C) The Author(s) 2020

\begin{abstract}
T-type, low-voltage activated, calcium channels, now designated Cav3 channels, are involved in a wide variety of physiological functions, especially in nervous systems. Their unique electrophysiological properties allow them to finely regulate neuronal excitability and to contribute to sensory processing, sleep, and hormone and neurotransmitter release. In the last two decades, genetic studies, including exploration of knock-out mouse models, have greatly contributed to elucidate the role of Cav3 channels in normal physiology, their regulation, and their implication in diseases. Mutations in genes encoding Cav3 channels (CACNA1G, CACNA1H, and CACNA1I) have been linked to a variety of neurodevelopmental, neurological, and psychiatric diseases designated here as neuronal Cav3 channelopathies. In this review, we describe and discuss the clinical findings and supporting in vitro and in vivo studies of the mutant channels, with a focus on de novo, gain-of-function missense mutations recently discovered in CACNAIG and CACNA1H. Overall, the studies of the Cav3 channelopathies help deciphering the pathogenic mechanisms of corresponding diseases and better delineate the properties and physiological roles Cav3 channels.
\end{abstract}

Keywords Calcium channels $\cdot$ T-type $\cdot$ Calcium channelopathies $\cdot$ Epilepsy $\cdot$ Ataxia $\cdot$ Autism $\cdot$ Schizophrenia $\cdot$ Primary aldosteronism

\section{Introduction}

In the early 1980s, Llinas and Yarom [91] reported that hyperpolarization of inferior olivary neurons of the cerebellum could reveal a low-threshold $\mathrm{Ca}^{2+}$ conductance, which was inactivated at their resting membrane potential. The concept of low-voltage activated (LVA) $\mathrm{Ca}^{2+}$ current then arose in the neuroscience community as this conductance was described in many different types of neurons, including thalamic [90], sensory $[19,152]$, and hippocampal [165] neurons. This LVA $\mathrm{Ca}^{2+}$ current, also typical for its fast inactivation (Transient) and small unitary conductance (Tiny), was soon after named "T-type" $[110,112]$. The unique voltage sensitivity of T-type $\mathrm{Ca}^{2+}$ channels is particularly well suited to regulate neuronal

This article is part of the special issue on Channelopathies: from mutation to diseases in Pflügers Archiv-European Journal of Physiology

Philippe Lory

philippe.lory@igf.cnrs.fr

1 Institut de Génomique Fonctionnelle, CNRS, INSERM, University Montpellier, 141, rue de la Cardonille, 34094 Montpellier, France

2 LabEx 'Ion Channel Science and Therapeutics' (ICST), Montpellier, France excitability and their oscillatory behavior near the resting membrane potential. A transient membrane hyperpolarization arising from inhibitory post-synaptic potentials (IPSPs) or activation of potassium $\left(\mathrm{K}^{+}\right)$channels deinactivates T-type channels. A subsequent rebound in the membrane potential triggers opening of T-type channels and favors a lowthreshold spike (LTS) that initiates rebound burst firing (Fig. 1a). The role of T-type channels in bursting behavior is physiologically relevant, especially in sleep $[5,84]$ with the generation of sleep spindles. In the last two decades, following the molecular cloning of the Cav3 (T-type) channels in the 2000s, genetic studies have greatly contributed to elucidate the role of T-type channels in normal physiology, as well as to identify their implication in diseases. Notably, mutations in the genes encoding the Cav3 channels have been linked essentially to neurodevelopmental, neurological, and psychiatric diseases designated here as neuronal Cav3 channelopathies.

\section{Cav3 channels: from molecular to physiological diversity}

\section{Cav3 molecular diversity}

Before the cloning era, a diversity within T-type channels was already proposed, based on observed differences in 
Fig. 1 Electrophysiological properties of T-type/Ca3 channels. a Illustration of the implication of Cav3.1 channels in rebound burst firing in thalamocortical relay neurons, as reported in [81].

Hyperpolarization deinactivates T-type channels, which promotes low-threshold spike and rebound burst firing. This firing activity in completely lost in thalamocortical relay neurons from $\mathrm{Cav} 3.1^{-/}$ mice (for details, see [81]). b Current traces for Cav3.1,

Cav3.2, and Cav3.3 channels obtained in HEK-293 cells, illustrating their differences in inactivation kinetics (see [13, 28]). c Illustration of the Cav3 window current that occurs in the range of the resting membrane potential

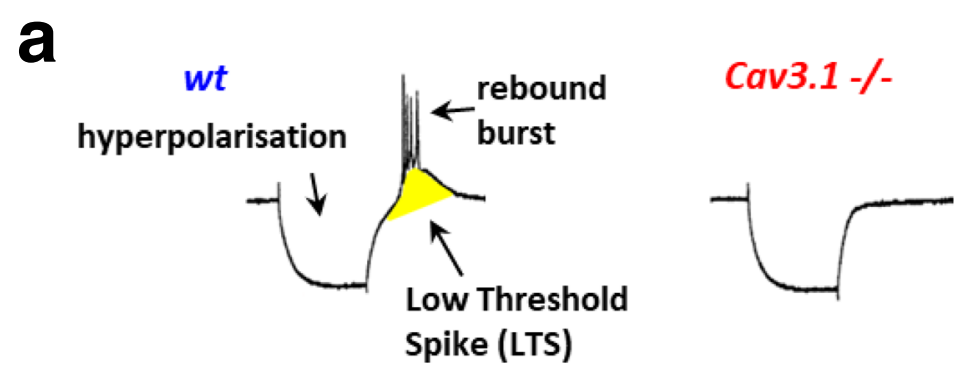

b
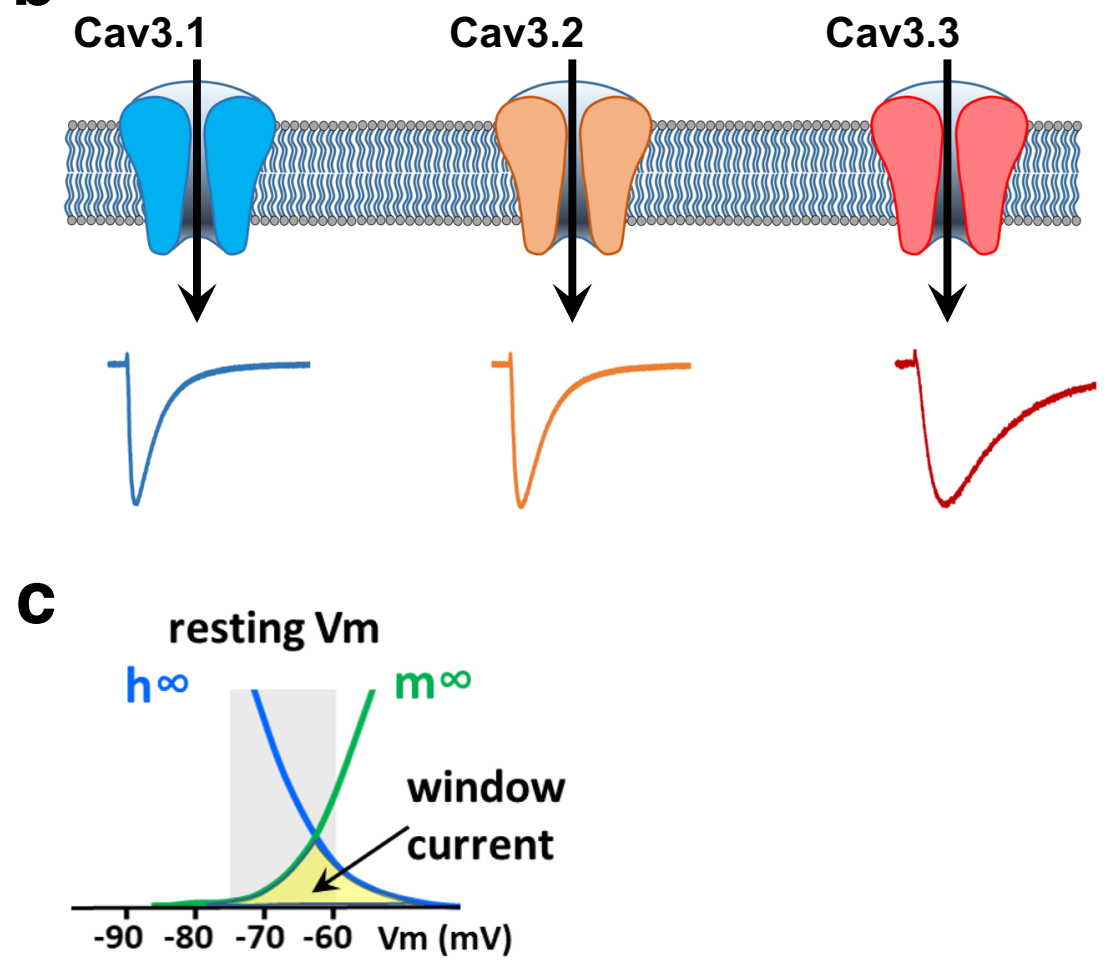

inactivation properties and sensitivity to blockers, such as nickel $\left(\mathrm{Ni}^{2+}\right)$ ions [74]. The first cDNA coding for the pore-forming subunit of a T-type channel was cloned in 1998 by Perez-Reyes and colleagues [119]. This was followed by extensive molecular cloning of several paralogs (isoforms) and orthologs, mainly in vetebrates, leading to the actual landscape of three genes (CACNAIG, CACNA1H, and CACNAII) encoding the $\alpha 1$ subunit of Ttype channels, Cav3.1 $\left(\alpha_{1 \mathrm{G}}\right)$, Cav3.2 $\left(\alpha_{1 \mathrm{H}}\right)$, and Cav3.3 $\left(\alpha_{11}\right)$, respectively (Figs. 1, 2, and 3) (for representative reviews, see $[117,118,158])$. The distinctive features of $\mathrm{T}$ type channels making them well suited to regulate excitability (low voltage range for activation, ion selectivity, fast kinetics for activation and inactivation) are conserved in the most early-diverging animals, such as in Trichoplax adhaerens, which expresses a single Cav3 channel [135]. Hence, genome survey in Salpingoeca rosetta indicates that
Cav3 channels have emerged more than a billion years ago in an eukaryotic ancestor of choanoflagellates and metazoans [103].

In mammals, the functional diversity in T-type channels arises not only from the three genes expressing Cav3 isoforms with distinct electrophysiological properties $[13,28]$ but also from several alternative splicing events [56, 98, 99, 118]. Alternative splicing can generate multiple variants from a single Cav3 isoform with significantly distinct electrophysiological properties and drug sensitivity $[25,26,54,83,101,105$, 132, 172]. Also, alternative splicing can regulate the Cav3 channel expression at the plasma membrane [133]. Alternative splicing could contribute to the clinical severity of Cav3 channelopathies, as documented by in vitro studies showing that disease-associated mutations exhibit distinct electrophysiological properties when reproduced in different splice variants $[66,122]$. 
Fig. 2 Schematic representation of the main Cav3 regulations (for previous reviews, see $[29,73,75$, 170]). The yellow asterisks point to the Cav3.2-selective

regulations, including the metal/ redox (His191, yellow circle) and glycosylation (Asn192, red circle) sites in S3-S4 extracellular linker of the domain I

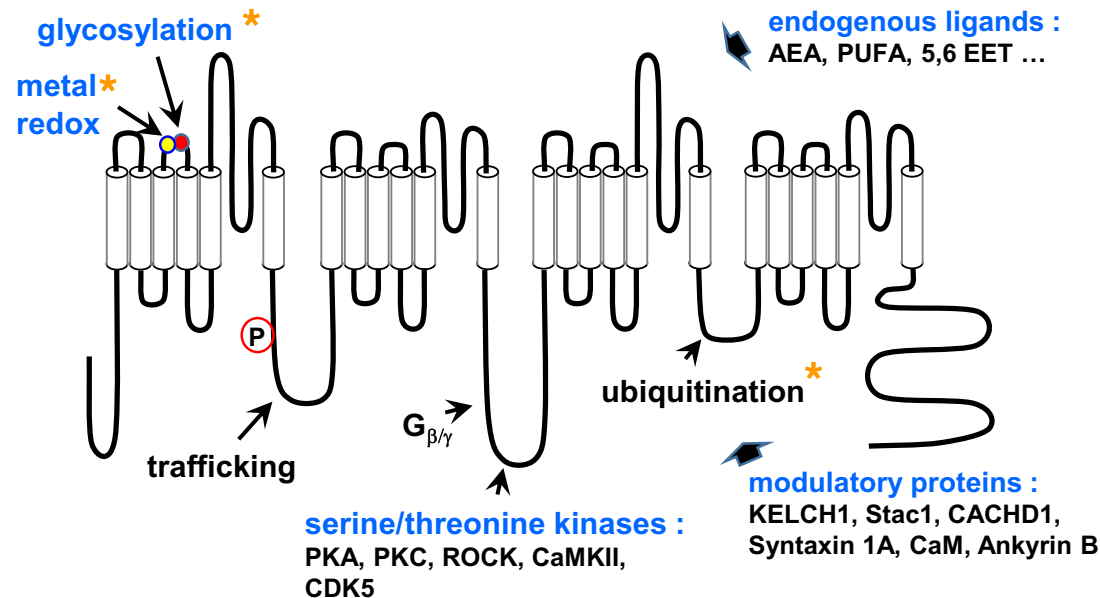

The tissue-specific expression of the Cav3 channels is clearly important to consider when investigating their physiological roles, as well as their implication in disease phenotypes [131]. In mammals, all Cav3 channels are expressed early during development. In adult, the three Cav3 isoforms are expressed mainly in the central and peripheral nervous systems and also in neuroendocrine and cardiac tissues [101, 102]. Within the brain, in situ hybridization studies have shown that the three Cav3 isoforms display both specific and distinct patterns of expression [12, 144]. In addition, Cav3 splice variants can be expressed in a tissue/cellspecific manner and be developmentally regulated [118]. Until now, the lack of highly specific antibodies for any of the Cav3 isoforms/variants has hampered precise analysis of their tissue and cellular and subcellular distribution at the protein level $[1,100,166]$, which was partly circumvented by the generation of knock-in (KI) animals carrying epitope-tagged Cav3 channels [8, 58].

\section{Cav3 physiology}

A hallmark of Cav3 channels is their unique ability to control neuronal excitability, requiring small membrane depolarizations to open (LVA), which distinguishes them from the high-voltage activated (HVA) channels [108, 168]. Their low threshold of voltage activation, coupled with their tonic
Fig. 3 Cladogram representation of the Cav channel family including the gene names and the corresponding Cav subunits. HVA stands for high-voltage activated channels (L-, P/Q-, N-, and R-types) and LVA stands for low-voltage activated channels (T-type). The channelopathies column refers to the overall socalled $\mathrm{Ca}^{2+}$ channelopathies, with the detailed properties of the Cav3 channelopathies presented and discussed in the text. The diseases caused by mutations in the S6 segments of the corresponding Cav channels are indicated (\#)

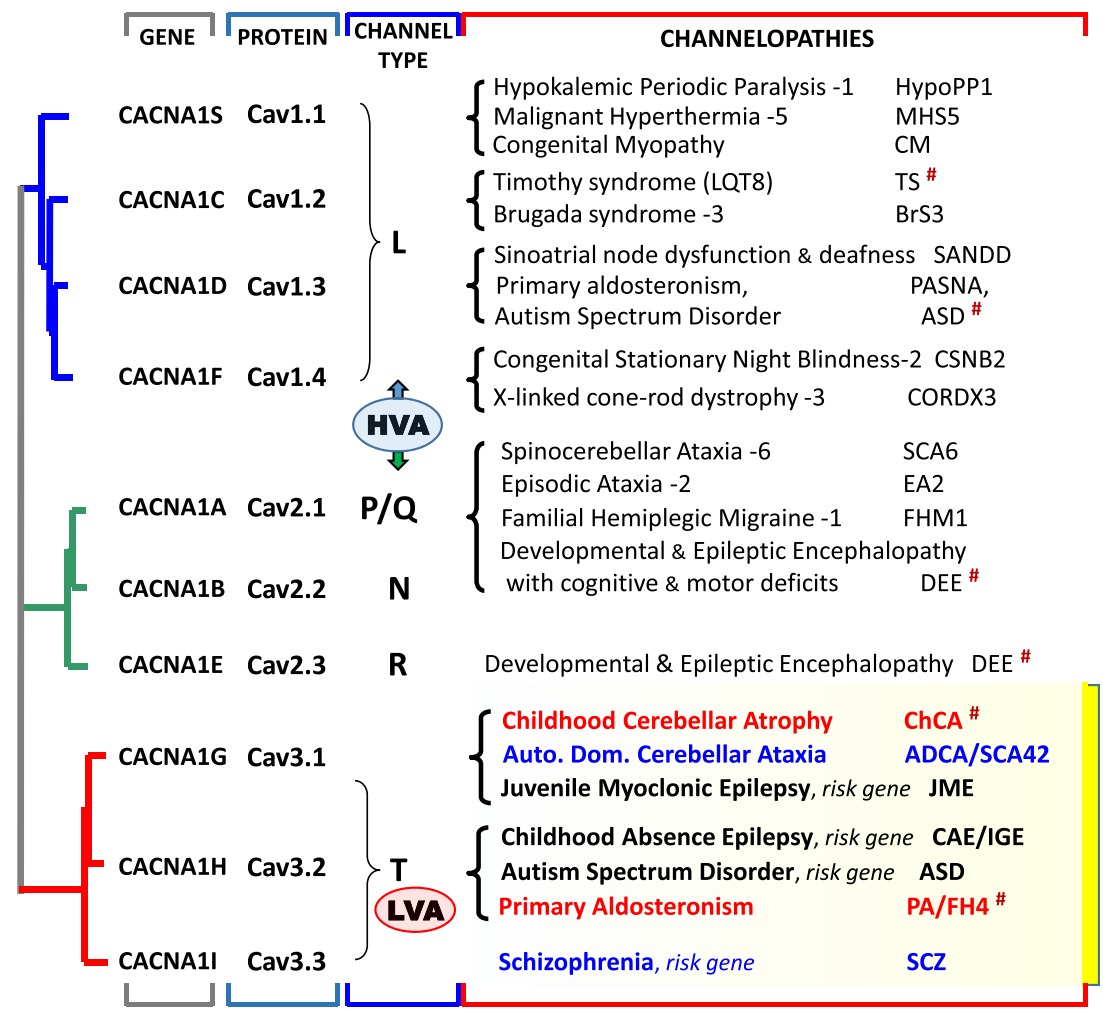


inactivation near resting membrane potential, allows Cav3 channels to deinactivate and to underly the low-threshold spike/rebound bursting phenomenon seen in many types of neurons (Fig. 1a). The three Cav3 isoforms, which exhibit distinct electrophysiological properties [13, 28] (Fig. 1b), regulate differentially neuronal excitability $[12,39,100]$. In addition, the $\mathrm{Ca}^{2+}$ influx through Cav3 channels can also directly regulate intracellular $\mathrm{Ca}^{2+}$ concentrations [24, 51]. Indeed, all three Cav3 channels display an overlap of their steady-state inactivation and activation properties giving rise to a window current (Fig. 1c) that ressembles a "background" $\mathrm{Ca}^{2+}$ current [153]. It results from the activity of a small fraction of Cav3 channels remaining open in the voltage range near the resting membrane potential $[34,40]$. The physiological role of this Cav3 window current is still poorly understood. It was shown to contribute to the slow oscillation in non-REM sleep [46].

Genetic manipulation of Cav3 expression in the mouse has provided significant information regarding the physiological roles of neuronal Cav3 channels and a quick overview of the findings obtained with Cav3 knock-out (KO) mouse models is provided here. In KO mice for Cacnalg (Cav3.1 $1^{-/-}$), no LVA T-type current could be recorded in thalamocortical relay neurons and these neurons showed no burst firing activity [81] (Fig. 1a). In these animals, spike-and-wave discharges that occur in absence epilepsy models were prevented. The loss of thalamocortical oscillations was also observed in central medial nucleus, which reflects the overall importance of Cav3.1 channels in thalamic neurons [146]. Cav3.1 $1^{-/-}$mice were less prone to develop tonic seizures in the maximal electroshock seizure test, compared with wt littermates and Cav3.2 $2^{-/-}$mice, suggesting a prominent role of the Cav3.1 isoform in mediating tonic seizure [127]. Interestingly, overexpression of the Cav3.1 channel in a Cacnalg transgenic mouse line results in a pure absence epilepsy phenotype with no ataxia or other neurological disturbances [57], suggesting that an increase in Cav3.1 current is sufficient to the pathogenesis of spike-wave seizures. Cav3.1 $1^{-/}$animals display a deficit in motor performance and in cerebellar learning [23, 94] and are resistant to harmaline-induced tremor [115]. In these animals, the T-type current was also significantly reduced in the subiculum, which is involved in hippocampaldependent cognitive processes [79].

The KO mice for Cacnalh $\left(\mathrm{Cav} 3.2^{-/-}\right.$) exhibit a variety of phenotypes including neurological deficits [36]. The nociceptive role of Cav3.2 channels, which are highly expressed in the dorsal root sensory neurons [10, 11, 136], was validated using these Cav3.2 KO animals [41, 147] and further established when Cav3.2 channels were selectively deleted in lowthreshold mechanoreceptor primary afferent neurons [58]. In the brain, Cav3.2 is predominantly expressed in the dentate gyrus of the hippocampus $[1,8]$. In Cav3.2 $2^{-/}$animals subjected to pilocarpine-induced status epilepticus, which models temporal lobe epilepsy, the appearance of epileptic seizures was strongly attenuated, validating the pro-epileptogenesis role of upregulated hippocampal Cav3.2 channels [7, 151]. In addition, Cav3.2 $2^{-/-}$mice show elevated anxiety and impaired hippocampus-dependent contextual memory and learning $[38,59]$.

Inactivation of Cacnali in the mouse $\left(\mathrm{Cav} 3.3^{-1-}\right)$ resulted in the loss of $\mathrm{LVA} \mathrm{Ca}^{2+}$ currents in the thalamic reticular nucleus (nRT) neurons and revealed a role of Cav3.3 channels in sleep. Cav3.3 channels dominate nRT rhythmogenesis and play a role in sleep spindles, the electroencephalographic hallmark of non-rapid eye movement (NREM) sleep [5, 85]. Of note, experiments performed in double Cav3.3 and Cav3.2 $\mathrm{KO}$ mice revealed that the lack of Cav3.2 channels further aggravates neuronal, synaptic, and EEG deficits in the Cav3.3 $3^{-/-}$background, indicating a role of Cav3.2 channels in regulating $\mathrm{nRT}$ excitability and rhythmogenesis [116, 145].

\section{Cav3 modulation}

There is no evidence for a requirement of protein-protein association to obtain "native-like" properties of T-type channels when the Cav3 proteins are expressed in heterologous systems, as the HEK-293 cell line. This is contrasting with HVA Ca ${ }^{2+}$ channels, the L-type Cav1.1 to Cav1.4, and neuronal Cav2.1 P/Q-type, Cav2.2 N-type and Cav2.3 R-type, which require the auxiliary $\alpha 2 / \delta, \beta$, and $\gamma$ subunits for their proper expression and function (reviewed in [108, 168]). However, a regulatory role of several proteins was identified for Cav3 channels, including the HVA auxiliary subunits [52], Kelch-like 1 [3], Stac1 [126], or the putative " $\mathrm{Ca}^{2+}$ channel and chemotaxis receptor domain containing 1," CACHD1 [43] (Fig. 2). Regulation of Cav3 channels by such endogenous proteins would more likely reflect the numerous signalling pathways targeting Cav3 channels, as reported for the $G$ protein $\beta \gamma$-dimer [50, 162], calmodulin [33, 86], syntaxin-1A [159], and spectrin $\alpha / \beta$ and ankyrin B [61] (Fig. 2).

The fine tuning of the functional properties of Cav3 channels by a large variety of endogenous pathways and ligands is now well established [29, 73, 75, 170] (Fig. 2). One of the first endogenous modulations described for Cav3 channels was the inhibitory effect of the endocannabinoid anandamide [27]. Other bioactive lipids, including arachidonic acid [143], Nacyl ethanolamides and polyunsaturated fatty acids [31], or 5,6-EET [21], were shown to also inhibit Cav3 channels in the micromolar range through a direct interaction [32]. Cav3 channels are also modulated by phosphorylation pathways, including the serine/threonine kinases, PKA and PKC [30, 71], $\mathrm{Ca}^{2+} / \mathrm{CaM}-d e p e n d e n t$ protein kinase II (CaMKII) [4, 161], rho-associated kinase (ROCK) [76], CDK5 [63], exchange factor activated by $c A M P$ (Epac) [111], and hypoxia-inducible factor (HIF) [18]. As demonstrated for Cav3.2 channels, the phosphorylation status greatly influences the gating properties [9]. Phosphorylation also regulates 
an activity-dependent $\mathrm{Ca}^{2+}$ inhibition recently discovered for Cav3 channels, especially Cav3.3 [22, 35]. Other posttranslational modifications regulating Cav3 channels, here Cav3.2 channels, including ubiquitination [60] and glycosylation $[114,160]$ have also been described. These latter studies point out that Cav3 isoform-specific modulations exist and are important to investigate further as they represent physiologically relevant selective regulations (Fig. 2). Of interest, the metal/redox modulation of T-type channels is also Cav3.2specific. Cav3.2 channels are selectively upregulated by reducing agents such as L-cysteine, while the oxidizing agent ascorbate produces Cav3.2 channel inhibition [148]. This redox regulation occurs through the metal-catalyzed oxidation of a histidine residue (His191 in the human isoform) localized in the extracellular S3-S4 linker of domain I of Cav3.2 channel $[72,80]$. Cav3.2 channels are also preferentially inhibited by the trace metal zinc $\left(\mathrm{Zn}^{2+}\right)$ with an $\mathrm{IC}_{50}$ in the submicromolar range $(\sim 0.8 \mu \mathrm{M})$, which is 100 - and 200 fold lower than Cav3.1 and Cav3.3 channels, respectively [149]. Further studies, using a KI mouse model, have demonstrated that His 191 is important for fine tuning of neuronal excitability in dorsal root sensory neurons [156].

\section{Cav3 channelopathies}

\section{CACNA1G/Cav3.1 in late-onset cerebellar ataxia ADCA/SCA42}

The Cav3.1 channel is highly expressed in the cerebellum, especially in Purkinje neurons [144], and was therefore a likely candidate for cerebellar disorders, especially ataxia. Hereditary cerebellar ataxias are rare neurodegenerative disorders, characterized by a cerebellar syndrome (gait alteration, limb incoordination, dysarthria, eye movement anomalies) with or without other neurological symptoms [45]. Using linkage analysis and whole-exome sequencing, CACNA1G was linked to an autosomal dominant cerebellar ataxia (ADCA) phenotype in three families, supporting its implication in spinocerebellar ataxia SCA42 [44] (Fig. 3). A recurrent missense mutation causing the p.Arg1715His substitution in the voltage sensor S4 segment of domain IV (IVS4, Fig. 4) of Cav3.1 was identified in these three unrelated pedigrees. This p.Arg1715His mutation affects the gating properties of the Cav3.1 channel with the steady-state activation properties shifted positively when expressed in HEK-293 cells. The expected reduction in channel activity was confirmed using computer modeling in deep cerebellar nuclei neurons that showed a decreased neuronal excitability. SCA42 is characterized by a slowly progressive ataxia with a variable onset but mainly in young adulthood. Athough the prevalence of SCA42 is very low, the association of this p.Arg1715HisCav3.1 mutation with SCA42 was subsequently confirmed in Japanese and Chinese families [82, 88, 104, 109]. Additional CACNA1G missense mutations have been identified in other SCA42 patients, including p.Arg1068Cys, p.His $1611 \mathrm{Gln}$, and p.Pro2273His variants. However, they have shown no statistically significant electrophysiological effect in heterologous expression systems [44], while the variant p.Met1574Lys [88] has not been yet electrophysiologically explored. These additional $C A C N A 1 G$ variants clearly require further functional analysis to validate them as SCA42causative mutations. Recently a KI mouse model of SCA42 was generated [65], harboring the above described mutation (p.Arg1723His in the mouse). Both heterozygous and homozygous KI mice demonstrated an adult-onset mild ataxia phenotype with comparable levels of motor impairment using rotarod and footprint tests, confirming the dominant inheritance of SCA42. Significant Purkinje neuron loss and degeneration of the molecular layer were also observed. This mouse model of SCA42 recapitulates well the observations made in SCA42 patients, as well as the electrophysiological analyses showing a positive shift of the voltage dependence of Cav3.1 channels [44]. Overall, this study confirms that SCA42 is caused by the p.Arg1715His mutation in Cav3.1 [65].

\section{CACNA1G/Cav3.1 in childhood cerebellar atrophy}

Another set of de novo $C A C N A 1 G$ mutations was identified in a cohort of infants with childhood cerebellar atrophy (ChCA), using a combination of candidate gene panel and wholeexome sequencing [34]. ChCA is a devastating infantile neurodevelopmental disorder, with severe motor and cognitive impairments, cerebellar atrophy, and variable features including facial dysmorphism, digital anomalies, microcephaly, hirsutism, and epilepsy. Two mutations were identified in four individuals, three patients carrying a p.Ala961 Thr mutation (in the Cav3.1 IIS6 segment) and one patient carrying a p.Met1531Val mutation (in the Cav3.1 IIIS6 segment) [34] (Fig. 4). Both mutations drastically altered the channel gating properties, especially the inactivation properties, with a significant slowing of the inactivation kinetics (5 times) and a negative shift $(-10 \mathrm{mV})$ of the potential for half-inactivation. In addition, these two mutations promoted a much larger window current that was fully inhibited by TTA-P2, a selective Cav3 channel blocker [34]. Overall, this study has demonstrated that p.Ala961Thr and p.Met1531Val are gain-offunction mutations. Importantly, this first description of de novo dominant $C A C N A 1 G$ mutations causing ChCA was confirmed by a recent study reporting on the same mutations (p.Ala961Thr and p.Met1531 Val), identified in three patients and in one patient, respectively [6], strengthening the recurrence of these mutations in ChCA. The devastating consequence of ChCA gain-of-function mutations in humans reveals that Cav3.1 channel has a critical role in setting up cerebellar physiology during development. Further studies are 


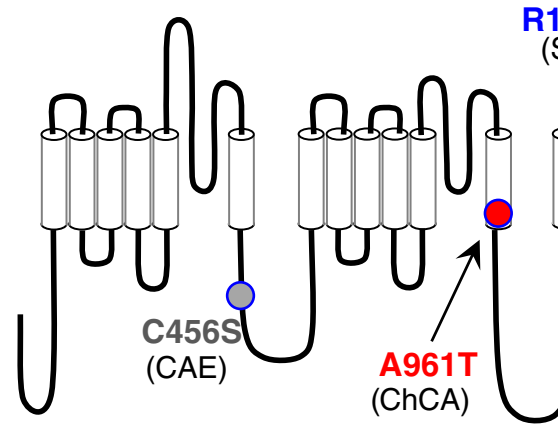

Fig. 4 Schematic localization of the main Cav3 mutations described in the text, including (i) the Cav3.1 mutations: p.Arg1715His in SCA42 [44, 65], p.Arg961Thr and p.Met1531Val in ChCA [6, 34]; (ii) the Cav3.2

necessary to uncover the pathogenic mechanism underlying the ChCA condition and to establish more precisely the developmental and functional roles of Cav3.1 channels in the cerebellum.

\section{CACNA1G/Cav3.1 in epilepsy}

Because of their presence in cortical and thalamic structures and their role in modulating neuronal firing, T-type channels have always been considered candidates for idiopathic generalized epilepsies (IGEs). Interestingly, it was shown that Cacnalg is a genetic modifier of epilepsy in a mouse model of Dravet syndrome caused by mutations in the voltage-gated $\mathrm{Na}^{+}$channel gene $S c n 1 a$ [16], as well as a modifier in a $S c n 2 a$ mouse model of focal epilepsy [15]. In humans, mutations in $C A C N A 1 G$ have been reported in juvenile myoclonic epilepsy patients [134]. However, the two reported missense mutations coding for p.Ala570Val and p.Ala1089Ser substitutions had no electrophysiological effect when explored in heterologous expression system, questioning their pathogenic status on a monogenic basis. A recent study has documented that IGEs have complex (oligogenic or multigenic) inheritance patterns with a likely combination of both common and rare genetic risk variants required to cause the disease. Among them, $C A C N A 1 G$, carrying a high number of missense variants in IGEs samples, still represents a susceptibility gene [55].

\section{CACNA1G/Cav3.1 in other neurological diseases}

Potential disease-causing variants in $C A C N A 1 G$ have also been identified in intellectual disability/cognitive disorders [106] and monoallelic deletions of the CACNAIG gene have been associated with mild intellectual disability without cerebellum atrophy [123]. Also, CACNA1G was identified as a candidate gene for autism spectrum disorder (ASD) in a subset of cases [142] but the CACNAIG association with ASD has yet to be replicated in a larger study [48]. CACNA1G also appeared to be a candidate gene in essential tremor, one of the most common movement disorders, with $C A C N A 1 G$

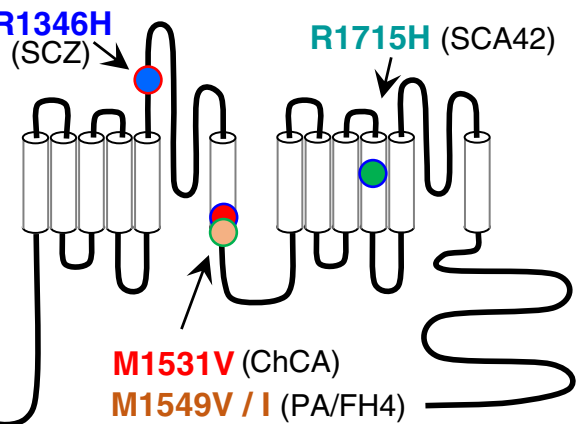

mutations: p.Arg1549Val and p.Arg1549Ile in PA/FH4 [47, 130], and p.Cys456Ser in CAE $[53,155]$; and (iii) the Cav3.3 mutation: p.Arg1346His in SCZ [2, 62]

variants identified in three families [113]. It is therefore likely that the clinical spectrum of diseases associated with $C A C N A 1 G$ mutations will increase in a near future.

\section{CACNA1H/Cav3.2 in epilepsy}

The $C A C N A 1 H$ gene, as $C A C N A 1 G$, has received much attention regarding its potential implication in inherited epilepsy phenotypes. In some spontaneous mouse models of generalized epilepsy, the tottering ( $t g)$, lethargic (lh), and stargazer (stg) mouse strains, an increase in T-type current density was observed [169]. Strikingly, in the GAERS rat (Genetic Absence Epilepsy Rats from Strasbourg), a missense mutation, p.Arg1584Pro in Cacnalh, was found to co-segregate with the slow-wave discharge phenotype [150]. In heterologous expression system, this missense substitution in the intracellular loop linking the domains III to IV (LIII-IV) could induce a gain of channel activity when introduced in a Cav3.2 splice variant containing exon 25 [14, 122].

In humans, several studies have reported associations between $C A C N A 1 H$ single nucleotide polymorphisms (SNPs) and epileptic phenotypes, especially in idiopathic generalized epilepsy (IGE) [42, 69, 87, 138], reviewed in [158, 167], since the first report by Chen et al. [37] describing CACNA1H SNPs in childhood absence epilepsy (CAE) patients. Functional studies of several of these $C A C N A 1 H$ missense variants revealed that they could modify biophysical properties or protein trafficking of Cav3.2 in heterologous expression systems $[69,154,155]$, in a loss- or gain-of-function manner. Many of these missense variants were found in the intracellular loop linking the domains I and II (LI-II) of Cav3.2 and one of them, p.Cys456Ser (Fig. 4), significantly increased spontaneous firing and reduced the threshold for rebound burst firing, when overexpressed in hippocampal neurons [53]. Yet, to date, none of these $C A C N A 1 H$ variants has been undoubtedly identified as causing seizure phenotypes. In other words, CACNAIH variants are not causing monogenic epilepsy [17]. As for CACNA1G, CACNA1H variants should be 
considered a risk factor for developing epilepsy, most likely implicating other genetic and/or environmental factors [67].

\section{CACNA1H/Cav3.2 in other neurological diseases}

Four missense variants in the $C A C N A 1 H$ gene were identified in six individuals with ASD and the corresponding Cav3.2 variants showed altered electrophysiological properties in heterologous expression [140]. Whether these $C A C N A 1 H$ variants segregate with the ASD phenotype remains to be validated as these variations have low penetrance and some of them were also found in unaffected individuals. Additional $C A C N A 1 H$ variants were reported in a patient with persistent pain [137] and in patients with amyotrophy lateral sclerosis $[125,141]$. Again, further studies are needed to validate association of $C A C N A 1 H$ variation with these conditions.

\section{CACNA1H/Cav3.2 in primary aldosteronism}

Using whole-exome sequencing, Scholl et al. [130] identified a recurrent missense mutation, p.Met1549Val, in the CACNA1H gene in five unrelated patients from a cohort of patients diagnosed with primary aldosteronism (PA) in early childhood (Fig. 3). This point mutation resulted in a significant gain of Cav3.2 channel activity. Soon after, Daniil et al. [47] also performing whole-exome sequencing in PA patients reported another substitution at this residue, p.Met1549Val, with similar gain-of-function properties. Additional gain-offunction mutations, p.Ser196Leu, p.Pro2083Leu, and p.Val1951Glu, were also identified in this study [47]. If one patient was diagnosed with minor mental retardation and multiplex developmental disorder, other patients showed no apparent signs of seizures, cardiac arrhythmia, or muscular or neurological alterations. CACNA1H-related PA is now defined as familial hyperaldosteronism type 4 (FH4; [120]).

The Met1549 amino acid is located in highly conserved sequence of the IIIS6 segment of Cav3.2 that lines the inner part of the channel pore and is involved in channel inactivation [97] (Fig. 4), indeed at the same position as Met1531 in Cav3.1 (Fig. 3). The two pathogenic substitutions of Met1549 (Val and Ile) confer ultraslow inactivation kinetics, significant negative shift in the steady-state inactivation properties, and an increased window current. These data support an increase in channel activity and a rise in intracellular $\mathrm{Ca}^{2+}[47,130]$. Notably, all these mutants led to increased aldosterone production and increased expression of the genes coding for steroidogenic enzymes in the adrenocortical H295R cell line after $\mathrm{K}^{+}$stimulation $[47,124]$. Additional $C A C N A 1 H$ mutations causing PA/FH4 will likely be identified, as exemplified by the recent description of a p.Ile1430Thr substitution (IIIS5 segment), in an aldosterone-producing adenoma [107].
CACNA1//Cav3.3 in neurological/psychiatric diseases

Genome-wide association studies (GWAS), as well as the identification of de novo variants in the CACNAII gene, have contributed to implicate $C A C N A 1 I$ as a genetic risk factor in schizophrenia (SCZ) $[64,77,129]$. When expressed in the HEK-293 cell line, one of the two Cav3.3 missense variations identified in [64], p.Arg1346His (Fig. 4), resulted in a lower expression level of the Cav3.3 protein, a reduced N-glycosylation, and a reduced expression at the plasma membrane, reducing the Cav3.3 current but with no change in the electrophysiological properties [2]. A KI mouse model was generated using the CRISPR/Cas9 editing approach to introduce the p.Arg1305His orthologous mutation [62]. The homozygous animals show altered excitability in the nRT and deficits in sleep spindle occurrence and at NREM/REM transitions. This animal model will facilitate further investigations of the role of Cav3.3 channels in impaired sleep spindle and nRT function in SCZ. Additional CACNAII variants have been identified in SCZ patients, confirming CACNAII as a genetic risk factor in SCZ [95, 163, 164]. CACNA1I is also considered a risk gene in autism [93] and other complex neuropsychiatric disorders [128].

\section{Conclusions and perspectives}

\section{De novo gain-of-function mutations in Cav3 channels: a wider group of S6-pathies?}

These last years, many novel disease-related Cav3 channel variants have been reported and some of them are causing severe disorders. This is the case for the de novo gain-offunction mutations in Cav3.1 and Cav3.2 channels in childhood cerebellar atrophy (ChCA) and primary aldosteronism (PA/FH4), respectively. These deleterious missense mutations involve residues, Ala961 and Met1531 in Cav3.1 and Met1549 in Cav3.2, in the highly conserved S6 segments lining the inner part of the pore channel (Fig. 4). These residues were implicated in Cav3 channel inactivation in earlier structure-function studies [49, 97]. Notably, these "S6 mutations" in Cav3.1 and Cav3.2 are reminiscent to several de novo gain-of-function mutations recently described in other genes encoding Cav channels (Fig. 3). These other Cav "S6 mutations" also cause severe, mainly neurodevelopmental, clinical phenotypes. S6 mutations in CACNA1C, which encodes the Cav1.2 L-type channel, cause Timothy syndrome (TS), a congenital long-QT cardiac arrhythmia with or without severe neurological phenotypes, including autism and mental retardation $[89,139]$. There are S6 mutations in CACNA1D, which encodes Cav1.3, another L-type channel, that causes a neurodevelopmental disorder including ASD, intellectual disability with or without neurological (hypotonia, epilepsy) and 
endocrine (primary aldosteronism or hyperinsulinemic hypoglycaemia) features (PASNA) [70, 121]. There are also S6 mutations in Cav2.3, the neuronal R-type channel encoded by CACNA1E, that causes developmental and epileptic encephalopathies (DEE) [68]. There is also recent evidence for de novo S6 mutations in CACNA1A, encoding the neuronal $\mathrm{P} /$ Q-type Cav2.1 channel, linked to severe DEE with intellectual disability and variable motor symptoms [78]. All these S6 missense mutations share functional features: they significantly impair the inactivation properties of the affected Cav channels, likely promoting increase in intracellular $\mathrm{Ca}^{2+}$ concentration and the subsequent cellular damages caused by abnormal $\mathrm{Ca}^{2+}$ homeostasis [96]. Considering the similarity in their pathogenic mechanism, we tentatively propose here to define this group of $\mathrm{Ca}^{2+}$ channelopathies as "S6-pathies." Further studies, exploiting animal models of the corresponding channelopathies, will help to identify the pathogenic mechanisms underlying the diseases and better delineate the precise implication(s) of the corresponding Cav channels. Deciphering the role of Cav3.1 and Cav3.2 in ChCA and PA/FH4, respectively, should benefit from a combined effort of the "calcium channelopathy" community.

\section{Structural studies of Cav3 channels: further deciphering of the disease mechanisms}

High-resolution structural studies can provide atomic-level views of disease mechanisms [20]. Notably, the Cryo-EM structure of the Cav3.1 channel was recently reported [171], opening new opportunities to better understand the molecular and functional consequences of disease mutations in Cav3.1 channel, as well as in Cav3.2 and Cav3.3 channels by homology modeling. It is also anticipated that the pharmacology of Cav3 channels will benefit from the development of novel therapeutic approaches using structure-guided drug discovery. Cav3/T-type channels have always been considered promising pharmacological targets considering their implication in a wide variety of neurological conditions, including epilepsy and pain. However, until now, the clinical development of drugs targeting Cav3 channels has not been as successful as expected [92, 157], likely because of the wide tissue expression of the Cav3 channels, the lack of selective Cav3 channel blockers, and, beyond that, the lack of Cav3 isoform-specific blockers. Further studies should establish whether there is a therapeutic potential of Cav3 blockers in the treatment of $\mathrm{ChCA}$ and $\mathrm{PA} / \mathrm{FH} 4$ diseases that are directly caused by increased activity of the Cav3.1 and Cav3.2 channels.

Acknowledgments This work is supported by the Labex "Ion Channel Science and Therapeutics" (ICST), Fondation Maladies Rares (FMR), Association Française contre les Myopathies (AFM), and Fondation pour la Recherche Médicale (FRM).

\section{Compliance with ethical standards}

Conflict of interest The authors declare that they have no conflict of interest.

Open Access This article is licensed under a Creative Commons Attribution 4.0 International License, which permits use, sharing, adaptation, distribution and reproduction in any medium or format, as long as you give appropriate credit to the original author(s) and the source, provide a link to the Creative Commons licence, and indicate if changes were made. The images or other third party material in this article are included in the article's Creative Commons licence, unless indicated otherwise in a credit line to the material. If material is not included in the article's Creative Commons licence and your intended use is not permitted by statutory regulation or exceeds the permitted use, you will need to obtain permission directly from the copyright holder. To view a copy of this licence, visit http://creativecommons.org/licenses/by/4.0/.

\section{References}

1. Aguado C, Garcia-Madrona S, Gil-Minguez M, Lujan R (2016) Ontogenic changes and differential localization of T-type $\mathrm{Ca}(2+)$ channel subunits Cav3.1 and Cav3.2 in mouse hippocampus and cerebellum. Front Neuroanat 10:83. https://doi.org/10.3389/fnana. 2016.00083

2. Andrade A, Hope J, Allen A, Yorgan V, Lipscombe D, Pan JQ (2016) A rare schizophrenia risk variant of CACNA1I disrupts CaV3.3 channel activity. Sci Rep 6:34233. https://doi.org/10. 1038/srep34233

3. Aromolaran KA, Benzow KA, Cribbs LL, Koob MD, PiedrasRenteria ES (2010) T-type current modulation by the actinbinding protein Kelch-like 1. Am J Physiol Cell Physiol 298: C1353-C1362. https://doi.org/10.1152/ajpcell.00235.2009

4. Asmara H, Micu I, Rizwan AP, Sahu G, Simms BA, Zhang FX, Engbers JDT, Stys PK, Zamponi GW, Turner RW (2017) A Ttype channel-calmodulin complex triggers alphaCaMKII activation. Mol Brain 10:37. https://doi.org/10.1186/s13041-017-03178

5. Astori S, Wimmer RD, Prosser HM, Corti C, Corsi M, Liaudet N, Volterra A, Franken P, Adelman JP, Luthi A (2011) The Ca(V)3.3 calcium channel is the major sleep spindle pacemaker in thalamus. Proc Natl Acad Sci U S A 108:13823-13828. https://doi.org/10. 1073/pnas. 1105115108

6. Barresi S, Dentici ML, Manzoni F, Bellacchio E, Agolini E, Pizzi S, Ciolfi A, Tarnopolsky M, Brady L, Garone G, Novelli A, Mei D, Guerrini R, Capuano A, Pantaleoni C, Tartaglia M (2020) Infantile-onset syndromic cerebellar ataxia and CACNA1G mutations. Pediatr Neurol 104:40-45. https://doi. org/10.1016/j.pediatrneurol.2019.09.005

7. Becker AJ, Pitsch J, Sochivko D, Opitz T, Staniek M, Chen CC, Campbell KP, Schoch S, Yaari Y, Beck H (2008) Transcriptional upregulation of Cav3.2 mediates epileptogenesis in the pilocarpine model of epilepsy. J Neurosci 28:13341-13353. https://doi. org/10.1523/JNEUROSCI.1421-08.2008

8. Bernal Sierra YA, Haseleu J, Kozlenkov A, Begay V, Lewin GR (2017) Genetic tracing of Cav3.2 T-type calcium channel expression in the peripheral nervous system. Front Mol Neurosci 10:70. https://doi.org/10.3389/fnmol.2017.00070

9. Blesneac I, Chemin J, Bidaud I, Huc-Brandt S, Vandermoere F, Lory P (2015) Phosphorylation of the Cav3.2 T-type calcium channel directly regulates its gating properties. Proc Natl Acad Sci U S A 112:13705-13710. https://doi.org/10.1073/pnas. 1511740112 
10. Bourinet E, Alloui A, Monteil A, Barrere C, Couette B, Poirot O, Pages A, McRory J, Snutch TP, Eschalier A, Nargeot J (2005) Silencing of the Cav3.2 T-type calcium channel gene in sensory neurons demonstrates its major role in nociception. EMBO J 24: 315-324. https://doi.org/10.1038/sj.emboj.7600515

11. Bourinet E, Francois A, Laffray S (2016) T-type calcium channels in neuropathic pain. Pain 157(Suppl 1):S15-S22. https://doi.org/ 10.1097/j.pain.0000000000000469

12. Broicher T, Kanyshkova T, Meuth P, Pape HC, Budde T (2008) Correlation of T-channel coding gene expression, IT, and the low threshold $\mathrm{Ca} 2+$ spike in the thalamus of a rat model of absence epilepsy. Mol Cell Neurosci 39:384-399. https://doi.org/10.1016/ j.men.2008.07.012

13. Cain SM, Snutch TP (2010) Contributions of T-type calcium channel isoforms to neuronal firing. Channels (Austin) 4:475482. https://doi.org/10.4161/chan.4.6.14106

14. Cain SM, Tyson JR, Choi HB, Ko R, Lin PJC, LeDue JM, Powell KL, Bernier LP, Rungta RL, Yang Y, Cullis PR, O'Brien TJ, MacVicar BA, Snutch TP (2018) CaV 3.2 drives sustained burst-firing, which is critical for absence seizure propagation in reticular thalamic neurons. Epilepsia 59:778-791. https://doi.org/ 10.1111/epi.14018

15. Calhoun JD, Hawkins NA, Zachwieja NJ, Kearney JA (2016) Cacnalg is a genetic modifier of epilepsy caused by mutation of voltage-gated sodium channel Scn2a. Epilepsia 57:e103-e107. https://doi.org/10.1111/epi.13390

16. Calhoun JD, Hawkins NA, Zachwieja NJ, Kearney JA (2017) Cacnalg is a genetic modifier of epilepsy in a mouse model of Dravet syndrome. Epilepsia 58:e111-e115. https://doi.org/10. 1111/epi.13811

17. Calhoun JD, Huffman AM, Bellinski I, Kinsley L, Bachman E, Gerard E, Kearney JA, Carvill GL (2020) CACNA1H variants are not a cause of monogenic epilepsy. Hum Mutat 41:1138-1144. https://doi.org/10.1002/humu.24017

18. Carabelli V, Marcantoni A, Comunanza V, de Luca A, Diaz J, Borges R, Carbone E (2007) Chronic hypoxia up-regulates alpha1H T-type channels and low-threshold catecholamine secretion in rat chromaffin cells. J Physiol 584:149-165. https://doi.org/ 10.1113/jphysiol.2007.132274

19. Carbone E, Lux HD (1984) A low voltage-activated, fully inactivating $\mathrm{Ca}$ channel in vertebrate sensory neurones. Nature 310:501-502. https://doi.org/10.1038/310501a0

20. Catterall WA, Lenaeus MJ, Gamal El-Din TM (2020) Structure and pharmacology of voltage-gated sodium and calcium channels. Annu Rev Pharmacol Toxicol 60:133-154. https://doi.org/10. 1146/annurev-pharmtox-010818-021757

21. Cazade M, Bidaud I, Hansen PB, Lory P, Chemin J (2014) 5,6EET potently inhibits T-type calcium channels: implication in the regulation of the vascular tone. Pflugers Arch 466:1759-1768. https://doi.org/10.1007/s00424-013-1411-0

22. Cazade M, Bidaud I, Lory P, Chemin J (2017) Activity-dependent regulation of T-type calcium channels by submembrane calcium ions. Elife 6. https://doi.org/10.7554/eLife.22331

23. Chang KY, Park YG, Park HY, Homanics GE, Kim J, Kim D (2011) Lack of CaV3.1 channels causes severe motor coordination defects and an age-dependent cerebellar atrophy in a genetic model of essential tremor. Biochem Biophys Res Commun 410:19-23. https://doi.org/10.1016/j.bbrc.2011.05.082

24. Chemin J, Monteil A, Briquaire C, Richard S, Perez-Reyes E, Nargeot J, Lory P (2000) Overexpression of T-type calcium channels in HEK-293 cells increases intracellular calcium without affecting cellular proliferation. FEBS Lett 478:166-172. https://doi. org/10.1016/s0014-5793(00)01832-9

25. Chemin J, Monteil A, Bourinet E, Nargeot J, Lory P (2001) Alternatively spliced alpha $(1 \mathrm{G})(\mathrm{Ca}(\mathrm{V}) 3.1)$ intracellular loops promote specific T-type $\mathrm{Ca}(2+)$ channel gating properties.
Biophys J 80:1238-1250. https://doi.org/10.1016/S00063495(01)76100-0

26. Chemin J, Monteil A, Dubel S, Nargeot J, Lory P (2001) The alpha1I T-type calcium channel exhibits faster gating properties when overexpressed in neuroblastoma/glioma NG 108-15 cells. Eur J Neurosci 14:1678-1686. https://doi.org/10.1046/j.0953816x.2001.01796.x

27. Chemin J, Monteil A, Perez-Reyes E, Nargeot J, Lory P (2001) Direct inhibition of T-type calcium channels by the endogenous cannabinoid anandamide. EMBO J 20:7033-7040. https://doi.org/ 10.1093/emboj/20.24.7033

28. Chemin J, Monteil A, Perez-Reyes E, Bourinet E, Nargeot J, Lory P (2002) Specific contribution of human T-type calcium channel isotypes (alpha $(1 \mathrm{G})$, alpha $(1 \mathrm{H})$ and alpha(1I)) to neuronal excitability. J Physiol 540:3-14. https://doi.org/10.1113/jphysiol.2001. 013269

29. Chemin J, Traboulsie A, Lory P (2006) Molecular pathways underlying the modulation of T-type calcium channels by neurotransmitters and hormones. Cell Calcium 40:121-134. https:// doi.org/10.1016/j.ceca.2006.04.015

30. Chemin J, Mezghrani A, Bidaud I, Dupasquier S, Marger F, Barrere C, Nargeot J, Lory P (2007) Temperature-dependent modulation of $\mathrm{CaV} 3 \mathrm{~T}$-type calcium channels by protein kinases $\mathrm{C}$ and A in mammalian cells. J Biol Chem 282:32710-32718. https:// doi.org/10.1074/jbc.M702746200

31. Chemin J, Nargeot J, Lory P (2007) Chemical determinants involved in anandamide-induced inhibition of T-type calcium channels. J Biol Chem 282:2314-2323. https://doi.org/10.1074/jbc. M610033200

32. Chemin J, Cazade M, Lory P (2014) Modulation of T-type calcium channels by bioactive lipids. Pflugers Arch 466:689-700. https://doi.org/10.1007/s00424-014-1467-5

33. Chemin J, Taiakina V, Monteil A, Piazza M, Guan W, Stephens RF, Kitmitto A, Pang ZP, Dolphin AC, Perez-Reyes E, Dieckmann T, Guillemette JG, Spafford JD (2017) Calmodulin regulates Cav3 T-type channels at their gating brake. J Biol Chem 292:20010-20031. https://doi.org/10.1074/jbc.M117. 807925

34. Chemin J, Siquier-Pernet K, Nicouleau M, Barcia G, Ahmad A, Medina-Cano D, Hanein S, Altin N, Hubert L, Bole-Feysot C, Fourage C, Nitschke P, Thevenon J, Rio M, Blanc P, Vidal C, Bahi-Buisson N, Desguerre I, Munnich A, Lyonnet S, Boddaert N, Fassi E, Shinawi M, Zimmerman H, Amiel J, Faivre L, Colleaux L, Lory P, Cantagrel V (2018) De novo mutation screening in childhood-onset cerebellar atrophy identifies gain-offunction mutations in the CACNA1G calcium channel gene. Brain 141:1998-2013. https://doi.org/10.1093/brain/awy145

35. Chemin J, Stamenic TT, Cazade M, Llinares J, Blesneac I, Todorovic SM, Lory P (2019) A novel phospho-modulatory mechanism contributes to the calcium-dependent regulation of T-type $\mathrm{Ca}(2+)$ channels. Sci Rep 9:15642. https://doi.org/10. 1038/s41598-019-52194-6

36. Chen CC, Lamping KG, Nuno DW, Barresi R, Prouty SJ, Lavoie JL, Cribbs LL, England SK, Sigmund CD, Weiss RM, Williamson RA, Hill JA, Campbell KP (2003) Abnormal coronary function in mice deficient in alpha1H T-type $\mathrm{Ca} 2+$ channels. Science 302:1416-1418. https://doi.org/10.1126/science.1089268

37. Chen Y, Lu J, Pan H, Zhang Y, Wu H, Xu K, Liu X, Jiang Y, Bao X, Yao Z, Ding K, Lo WH, Qiang B, Chan P, Shen Y, Wu X (2003) Association between genetic variation of CACNA1H and childhood absence epilepsy. Ann Neurol 54:239-243. https://doi. org/10.1002/ana.10607

38. Chen CC, Shen JW, Chung NC, Min MY, Cheng SJ, Liu IY (2012) Retrieval of context-associated memory is dependent on the Ca(v)3.2 T-type calcium channel. PLoS One 7:e29384. https:// doi.org/10.1371/journal.pone.0029384 
39. Cheong E, Shin HS (2014) T-type Ca2+ channels in absence epilepsy. Pflugers Arch 466:719-734. https://doi.org/10.1007/ s00424-014-1461-y

40. Chevalier M, Lory P, Mironneau C, Macrez N, Quignard JF (2006) T-type CaV3.3 calcium channels produce spontaneous low-threshold action potentials and intracellular calcium oscillations. Eur J Neurosci 23:2321-2329. https://doi.org/10.1111/j. 1460-9568.2006.04761.x

41. Choi S, Na HS, Kim J, Lee J, Lee S, Kim D, Park J, Chen CC, Campbell KP, Shin HS (2007) Attenuated pain responses in mice lacking $\mathrm{Ca}(\mathrm{V}) 3.2$ T-type channels. Genes Brain Behav 6:425431. https://doi.org/10.1111/j.1601-183X.2006.00268.x

42. Chourasia N, Osso-Rivera H, Ghosh A, Von Allmen G, Koenig MK (2019) Expanding the phenotypic spectrum of CACNA1H mutations. Pediatr Neurol 93:50-55. https://doi.org/10.1016/j. pediatrneurol.2018.11.017

43. Cottrell GS, Soubrane CH, Hounshell JA, Lin H, Owenson V, Rigby M, Cox PJ, Barker BS, Ottolini M, Ince S, Bauer CC, Perez-Reyes E, Patel MK, Stevens EB, Stephens GJ (2018) CACHD1 is an alpha2delta-like protein that modulates $\mathrm{CaV} 3$ voltage-gated calcium channel activity. J Neurosci 38:91869201. https://doi.org/10.1523/JNEUROSCI.3572-15.2018

44. Coutelier M, Blesneac I, Monteil A, Monin ML, Ando K, Mundwiller E, Brusco A, Le Ber I, Anheim M, Castrioto A, Duyckaerts C, Brice A, Durr A, Lory P, Stevanin G (2015) A recurrent mutation in CACNA1G alters Cav3.1 T-type calciumchannel conduction and causes autosomal-dominant cerebellar ataxia. Am J Hum Genet 97:726-737. https://doi.org/10.1016/j. ajhg.2015.09.007

45. Coutelier M, Coarelli G, Monin ML, Konop J, Davoine CS, Tesson C, Valter R, Anheim M, Behin A, Castelnovo G, Charles P, David A, Ewenczyk C, Fradin M, Goizet C, Hannequin D, Labauge P, Riant F, Sarda P, Sznajer Y, Tison F, Ullmann U, Van Maldergem L, Mochel F, Brice A, Stevanin G, Durr A, network S (2017) A panel study on patients with dominant cerebellar ataxia highlights the frequency of channelopathies. Brain 140:1579-1594. https://doi.org/10.1093/brain/awx081

46. Crunelli V, Lorincz ML, Connelly WM, David F, Hughes SW, Lambert RC, Leresche N, Errington AC (2018) Dual function of thalamic low-vigilance state oscillations: rhythm-regulation and plasticity. Nat Rev Neurosci 19:107-118. https://doi.org/10. 1038/nrn.2017.151

47. Daniil G, Fernandes-Rosa FL, Chemin J, Blesneac I, Beltrand J, Polak M, Jeunemaitre X, Boulkroun S, Amar L, Strom TM, Lory P, Zennaro MC (2016) CACNA1H mutations are associated with different forms of primary aldosteronism. EBioMedicine 13:225236. https://doi.org/10.1016/j.ebiom.2016.10.002

48. Deciphering Developmental Disorders S (2015) Large-scale discovery of novel genetic causes of developmental disorders. Nature 519:223-228. https://doi.org/10.1038/nature14135

49. Demers-Giroux PO, Bourdin B, Sauve R, Parent L (2013) Cooperative activation of the T-type CaV3.2 channel: interaction between domains II and III. J Biol Chem 288:29281-29293. https://doi.org/10.1074/jbc.M113.500975

50. DePuy SD, Yao J, Hu C, McIntire W, Bidaud I, Lory P, Rastinejad F, Gonzalez C, Garrison JC, Barrett PQ (2006) The molecular basis for T-type $\mathrm{Ca} 2+$ channel inhibition by $\mathrm{G}$ protein beta2gamma2 subunits. Proc Natl Acad Sci U S A 103:1459014595. https://doi.org/10.1073/pnas.0603945103

51. Dreyfus FM, Tscherter A, Errington AC, Renger JJ, Shin HS, Uebele VN, Crunelli V, Lambert RC, Leresche N (2010) Selective T-type calcium channel block in thalamic neurons reveals channel redundancy and physiological impact of I(T)window. J Neurosci 30:99-109. https://doi.org/10.1523/ JNEUROSCI.4305-09.2010
52. Dubel SJ, Altier C, Chaumont S, Lory P, Bourinet E, Nargeot J (2004) Plasma membrane expression of T-type calcium channel alpha(1) subunits is modulated by high voltage-activated auxiliary subunits. J Biol Chem 279:29263-29269. https://doi.org/10.1074/ jbc.M313450200

53. Eckle VS, Shcheglovitov A, Vitko I, Dey D, Yap CC, Winckler B, Perez-Reyes E (2014) Mechanisms by which a CACNA1H mutation in epilepsy patients increases seizure susceptibility. J Physiol 592:795-809. https://doi.org/10.1113/jphysiol.2013. 264176

54. Emerick MC, Stein R, Kunze R, McNulty MM, Regan MR, Hanck DA, Agnew WS (2006) Profiling the array of $\mathrm{Ca}(\mathrm{v}) 3.1$ variants from the human T-type calcium channel gene CACNA1G: alternative structures, developmental expression, and biophysical variations. Proteins 64:320-342. https://doi.org/ 10.1002/prot.20877

55. Epi25 Collaborative, Electronic address sbuea, Epi C (2019) Ultra-rare genetic variation in the epilepsies: a whole-exome sequencing study of 17,606 individuals. Am J Hum Genet 105:267282. https://doi.org/10.1016/j.ajhg.2019.05.020

56. Ernst WL, Noebels JL (2009) Expanded alternative splice isoform profiling of the mouse Cav3.1/alpha1G T-type calcium channel. BMC Mol Biol 10:53. https://doi.org/10.1186/1471-2199-10-53

57. Ernst WL, Zhang Y, Yoo JW, Ernst SJ, Noebels JL (2009) Genetic enhancement of thalamocortical network activity by elevating alpha $1 \mathrm{~g}$-mediated low-voltage-activated calcium current induces pure absence epilepsy. J Neurosci 29:1615-1625. https:// doi.org/10.1523/JNEUROSCI.2081-08.2009

58. Francois A, Schuetter N, Laffray S, Sanguesa J, Pizzoccaro A, Dubel S, Mantilleri A, Nargeot J, Noel J, Wood JN, Moqrich A, Pongs O, Bourinet E (2015) The low-threshold calcium channel Cav3.2 determines low-threshold mechanoreceptor function. Cell Rep 10:370-382. https://doi.org/10.1016/j.celrep.2014.12.042

59. Gangarossa G, Laffray S, Bourinet E, Valjent E (2014) T-type calcium channel Cav3.2 deficient mice show elevated anxiety, impaired memory and reduced sensitivity to psychostimulants. Front Behav Neurosci 8:92. https://doi.org/10.3389/fnbeh.2014. 00092

60. Garcia-Caballero A, Gadotti VM, Stemkowski P, Weiss N, Souza IA, Hodgkinson V, Bladen C, Chen L, Hamid J, Pizzoccaro A, Deage M, Francois A, Bourinet E, Zamponi GW (2014) The deubiquitinating enzyme USP5 modulates neuropathic and inflammatory pain by enhancing Cav3.2 channel activity. Neuron 83:1144-1158. https://doi.org/10.1016/j.neuron.2014.07.036

61. Garcia-Caballero A, Zhang FX, Hodgkinson V, Huang J, Chen L, Souza IA, Cain S, Kass J, Alles S, Snutch TP, Zamponi GW (2018) T-type calcium channels functionally interact with spectrin (alpha/beta) and ankyrin B. Mol Brain 11:24. https://doi.org/10. 1186/s13041-018-0368-5

62. Ghoshal A, Uygun DS, Yang L, McNally JM, Lopez-Huerta VG, Arias-Garcia MA, Baez-Nieto D, Allen A, Fitzgerald M, Choi S, Zhang Q, Hope JM, Yan K, Mao X, Nicholson TB, Imaizumi K, Fu Z, Feng G, Brown RE, Strecker RE, Purcell SM, Pan JQ (2020) Effects of a patient-derived de novo coding alteration of CACNA1I in mice connect a schizophrenia risk gene with sleep spindle deficits. Transl Psychiatry 10:29. https://doi.org/10.1038/ s41398-020-0685-1

63. Gomez K, Calderon-Rivera A, Sandoval A, Gonzalez-Ramirez R, Vargas-Parada A, Ojeda-Alonso J, Granados-Soto V, DelgadoLezama R, Felix R (2020) Cdk5-dependent phosphorylation of CaV3.2 T-type channels: possible role in nerve ligation-induced neuropathic allodynia and the compound action potential in primary afferent C fibers. J Neurosci 40:283-296. https://doi.org/10. 1523/JNEUROSCI.0181-19.2019

64. Gulsuner S, Walsh T, Watts AC, Lee MK, Thornton AM, Casadei S, Rippey C, Shahin H, Consortium on the Genetics of S, Group 
PS, Nimgaonkar VL, Go RC, Savage RM, Swerdlow NR, Gur RE, Braff DL, King MC, McClellan JM (2013) Spatial and temporal mapping of de novo mutations in schizophrenia to a fetal prefrontal cortical network. Cell 154:518-529. https://doi.org/10. 1016/j.cell.2013.06.049

65. Hashiguchi S, Doi H, Kunii M, Nakamura Y, Shimuta M, Suzuki E, Koyano S, Okubo M, Kishida H, Shiina M, Ogata K, Hirashima F, Inoue Y, Kubota S, Hayashi N, Nakamura H, Takahashi K, Katsumoto A, Tada M, Tanaka K, Sasaoka T, Miyatake S, Miyake N, Saitsu H, Sato N, Ozaki K, Ohta K, Yokota T, Mizusawa H, Mitsui J, Ishiura H, Yoshimura J, Morishita S, Tsuji S, Takeuchi H, Ishikawa K, Matsumoto N, Ishikawa T, Tanaka F (2019) Ataxic phenotype with altered CaV3.1 channel property in a mouse model for spinocerebellar ataxia 42 . Neurobiol Dis 130:104516. https://doi.org/10.1016/j.nbd.2019. 104516

66. He M, Xu Z, Zhang Y, Hu C (2019) Splice-variant-specific effects of primary aldosteronism point mutations on human CaV3.2 calcium channels. Cell Calcium 84:102104. https://doi.org/10.1016/ j.ceca.2019.102104

67. Helbig I, Riggs ER, Barry CA, Klein KM, Dyment D, Thaxton C, Sadikovic B, Sands TT, Wagnon JL, Liaquat K, Cilio MR, Mirzaa G, Park K, Axeen E, Butler E, Bardakjian TM, Striano P, Poduri A, Siegert RK, Grant AR, Helbig KL, Mefford HC (2018) The ClinGen Epilepsy Gene Curation Expert Panelbridging the divide between clinical domain knowledge and formal gene curation criteria. Hum Mutat 39:1476-1484. https:// doi.org/10.1002/humu.23632

68. Helbig KL, Lauerer RJ, Bahr JC, Souza IA, Myers CT, Uysal B, Schwarz N, Gandini MA, Huang S, Keren B, Mignot C, Afenjar A, Billette de Villemeur T, Heron D, Nava C, Valence S, Buratti J, Fagerberg CR, Soerensen KP, Kibaek M, Kamsteeg EJ, Koolen DA, Gunning B, Schelhaas HJ, Kruer MC, Fox J, Bakhtiari S, Jarrar R, Padilla-Lopez S, Lindstrom K, Jin SC, Zeng X, Bilguvar K, Papavasileiou A, Xing Q, Zhu C, Boysen K, Vairo F, Lanpher BC, Klee EW, Tillema JM, Payne ET, Cousin MA, Kruisselbrink TM, Wick MJ, Baker J, Haan E, Smith N, Sadeghpour A, Davis EE, Katsanis N, Task Force for Neonatal G, Corbett MA, MacLennan AH, Gecz J, Biskup S, Goldmann E, Rodan LH, Kichula E, Segal E, Jackson KE, Asamoah A, Dimmock D, McCarrier J, Botto LD, Filloux F, Tvrdik T, Cascino GD, Klingerman S, Neumann C, Wang R, Jacobsen JC, Nolan MA, Snell RG, Lehnert K, Sadleir LG, Anderlid BM, Kvarnung M, Guerrini R, Friez MJ, Lyons MJ, Leonhard J, Kringlen G, Casas K, El Achkar CM, Smith LA, Rotenberg A, Poduri A, Sanchis-Juan A, Carss KJ, Rankin J, Zeman A, Raymond FL, Blyth M, Kerr B, Ruiz K, Urquhart J, Hughes I, Banka S, Deciphering Developmental Disorders S, UBS H, Scheffer IE, Helbig I, Zamponi GW, Lerche H, Mefford HC (2018) De novo pathogenic variants in CACNA1E cause developmental and epileptic encephalopathy with contractures, macrocephaly, and dyskinesias. Am J Hum Genet 103:666-678. https://doi.org/10.1016/j.ajhg.2018.09.006

69. Heron SE, Khosravani H, Varela D, Bladen C, Williams TC, Newman MR, Scheffer IE, Berkovic SF, Mulley JC, Zamponi GW (2007) Extended spectrum of idiopathic generalized epilepsies associated with CACNA1H functional variants. Ann Neurol 62:560-568. https://doi.org/10.1002/ana.21169

70. Hofer NT, Tuluc P, Ortner NJ, Nikonishyna YV, FernandesQuintero ML, Liedl KR, Flucher BE, Cox H, Striessnig J (2020) Biophysical classification of a CACNA1D de novo mutation as a high-risk mutation for a severe neurodevelopmental disorder. Mol Autism 11:4. https://doi.org/10.1186/s13229-019-0310-4

71. Hu C, Depuy SD, Yao J, McIntire WE, Barrett PQ (2009) Protein kinase A activity controls the regulation of T-type CaV3.2 channels by Gbetagamma dimers. J Biol Chem 284:7465-7473. https://doi.org/10.1074/jbc.M808049200

72. Huang D, Shi S, Liang C, Zhang X, Du X, An H, Peers C, Zhang $\mathrm{H}$, Gamper N (2020) Delineating an extracellular redox-sensitive module in T-type $\mathrm{Ca}(2+)$ channels. J Biol Chem 295:6177-6186. https://doi.org/10.1074/jbc.RA120.012668

73. Huc S, Monteil A, Bidaud I, Barbara G, Chemin J, Lory P (2009) Regulation of T-type calcium channels: signalling pathways and functional implications. Biochim Biophys Acta 1793:947-952. https://doi.org/10.1016/j.bbamcr.2008.11.003

74. Huguenard JR (1996) Low-threshold calcium currents in central nervous system neurons. Annu Rev Physiol 58:329-348. https:// doi.org/10.1146/annurev.ph.58.030196.001553

75. Iftinca MC, Zamponi GW (2009) Regulation of neuronal T-type calcium channels. Trends Pharmacol Sci 30:32-40. https://doi. org/10.1016/j.tips.2008.10.004

76. Iftinca M, Hamid J, Chen L, Varela D, Tadayonnejad R, Altier C, Turner RW, Zamponi GW (2007) Regulation of T-type calcium channels by rho-associated kinase. Nat Neurosci 10:854-860. https://doi.org/10.1038/nn1921

77. Irish Schizophrenia Genomics C, the Wellcome Trust Case Control C (2012) Genome-wide association study implicates HLA-C*01:02 as a risk factor at the major histocompatibility complex locus in schizophrenia. Biol Psychiatry 72:620-628. https://doi.org/10.1016/j.biopsych.2012.05.035

78. Jiang X, Raju PK, D'Avanzo N, Lachance M, Pepin J, Dubeau F, Mitchell WG, Bello-Espinosa LE, Pierson TM, Minassian BA, Lacaille JC, Rossignol E (2019) Both gain-of-function and lossof-function de novo CACNA1A mutations cause severe developmental epileptic encephalopathies in the spectrum of LennoxGastaut syndrome. Epilepsia 60:1881-1894. https://doi.org/10. 1111/epi.16316

79. Joksimovic SM, Eggan P, Izumi Y, Joksimovic SL, Tesic V, Dietz RM, Orfila JE, DiGruccio MR, Herson PS, Jevtovic-Todorovic V, Zorumski CF, Todorovic SM (2017) The role of T-type calcium channels in the subiculum: to burst or not to burst? J Physiol 595: 6327-6348. https://doi.org/10.1113/JP274565

80. Kang HW, Vitko I, Lee SS, Perez-Reyes E, Lee JH (2010) Structural determinants of the high affinity extracellular zinc binding site on Cav3.2 T-type calcium channels. J Biol Chem 285: 3271-3281. https://doi.org/10.1074/jbc.M109.067660

81. Kim D, Song I, Keum S, Lee T, Jeong MJ, Kim SS, McEnery MW, Shin HS (2001) Lack of the burst firing of thalamocortical relay neurons and resistance to absence seizures in mice lacking alpha(1G) T-type $\mathrm{Ca}(2+)$ channels. Neuron 31:35-45. https://doi. org/10.1016/s0896-6273(01)00343-9

82. Kimura M, Yabe I, Hama Y, Eguchi K, Ura S, Tsuzaka K, Tsuji S, Sasaki H (2017) SCA42 mutation analysis in a case series of Japanese patients with spinocerebellar ataxia. J Hum Genet 62: 857-859. https://doi.org/10.1038/jhg.2017.51

83. Latour I, Louw DF, Beedle AM, Hamid J, Sutherland GR, Zamponi GW (2004) Expression of T-type calcium channel splice variants in human glioma. Glia 48:112-119. https://doi. org/10.1002/glia.20063

84. Lee J, Kim D, Shin HS (2004) Lack of delta waves and sleep disturbances during non-rapid eye movement sleep in mice lacking alpha1G-subunit of T-type calcium channels. Proc Natl Acad Sci U S A 101:18195-18199. https://doi.org/10.1073/pnas. 0408089101

85. Lee SE, Lee J, Latchoumane C, Lee B, Oh SJ, Saud ZA, Park C, Sun N, Cheong E, Chen CC, Choi EJ, Lee CJ, Shin HS (2014) Rebound burst firing in the reticular thalamus is not essential for pharmacological absence seizures in mice. Proc Natl Acad Sci U S A 111:11828-11833. https://doi.org/10.1073/pnas.1408609111

86. Lee N, Jeong S, Kim KC, Kim JA, Park JY, Kang HW, PerezReyes E, Lee JH (2017) $\mathrm{Ca}(2+)$ regulation of Cav3.3 T-type 
$\mathrm{Ca}(2+)$ channel is mediated by calmodulin. Mol Pharmacol 92: 347-357. https://doi.org/10.1124/mol.117.108530

87. Lee CG, Lee J, Lee M (2018) Multi-gene panel testing in Korean patients with common genetic generalized epilepsy syndromes. PLoS One 13:e199321. https://doi.org/10.1371/journal.pone. 0199321

88. Li X, Zhou C, Cui L, Zhu L, Du H, Liu J, Wang C, Fang S (2018) A case of a novel CACNA1G mutation from a Chinese family with SCA42: a case report and literature review. Medicine (Baltimore) 97:e12148. https://doi.org/10.1097/MD. 0000000000012148

89. Liao P, Soong TW (2010) CaV1.2 channelopathies: from arrhythmias to autism, bipolar disorder, and immunodeficiency. Pflugers Arch 460:353-359. https://doi.org/10.1007/s00424-009-0753-0

90. Llinas R, Jahnsen H (1982) Electrophysiology of mammalian thalamic neurones in vitro. Nature 297:406-408. https://doi.org/10. 1038/297406a0

91. Llinas R, Yarom Y (1981) Electrophysiology of mammalian inferior olivary neurones in vitro. Different types of voltagedependent ionic conductances. J Physiol 315:549-567. https:// doi.org/10.1113/jphysiol.1981.sp013763

92. Lory P, Chemin J (2007) Towards the discovery of novel T-type calcium channel blockers. Expert Opin Ther Targets 11:717-722. https://doi.org/10.1517/14728222.11.5.717

93. Lu AT, Dai X, Martinez-Agosto JA, Cantor RM (2012) Support for calcium channel gene defects in autism spectrum disorders. Mol Autism 3:18. https://doi.org/10.1186/2040-2392-3-18

94. Ly R, Bouvier G, Schonewille M, Arabo A, Rondi-Reig L, Lena C, Casado M, De Zeeuw CI, Feltz A (2013) T-type channel blockade impairs long-term potentiation at the parallel fiber-Purkinje cell synapse and cerebellar learning. Proc Natl Acad Sci U S A 110:20302-20307. https://doi.org/10.1073/pnas.1311686110

95. Manoach DS, Pan JQ, Purcell SM, Stickgold R (2016) Reduced sleep spindles in schizophrenia: a treatable endophenotype that links risk genes to impaired cognition? Biol Psychiatry 80:599 608. https://doi.org/10.1016/j.biopsych.2015.10.003

96. Mark MD, Schwitalla JC, Groemmke M, Herlitze S (2017) Keeping our calcium in balance to maintain our balance. Biochem Biophys Res Commun 483:1040-1050. https://doi.org/ 10.1016/j.bbrc.2016.07.020

97. Marksteiner R, Schurr P, Berjukow S, Margreiter E, Perez-Reyes E, Hering $S$ (2001) Inactivation determinants in segment IIIS6 of $\mathrm{Ca}(\mathrm{v}) 3.1$. J Physiol 537:27-34. https://doi.org/10.1111/j.14697793.2001.0027k.x

98. Mittman S, Guo J, Agnew WS (1999) Structure and alternative splicing of the gene encoding alpha1G, a human brain $\mathrm{T}$ calcium channel alpha1 subunit. Neurosci Lett 274:143-146. https://doi. org/10.1016/s0304-3940(99)00716-8

99. Mittman S, Guo J, Emerick MC, Agnew WS (1999) Structure and alternative splicing of the gene encoding alpha1I, a human brain T calcium channel alpha1 subunit. Neurosci Lett 269:121-124. https://doi.org/10.1016/s0304-3940(99)00319-5

100. Molineux ML, McRory JE, McKay BE, Hamid J, Mehaffey WH, Rehak R, Snutch TP, Zamponi GW, Turner RW (2006) Specific T-type calcium channel isoforms are associated with distinct burst phenotypes in deep cerebellar nuclear neurons. Proc Natl Acad Sci U S A 103:5555-5560. https://doi.org/10.1073/pnas.0601261103

101. Monteil A, Chemin J, Bourinet E, Mennessier G, Lory P, Nargeot J (2000) Molecular and functional properties of the human alpha(1G) subunit that forms T-type calcium channels. J Biol Chem 275:6090-6100. https://doi.org/10.1074/jbc.275.9.6090

102. Monteil A, Chemin J, Leuranguer V, Altier C, Mennessier G, Bourinet E, Lory P, Nargeot J (2000) Specific properties of Ttype calcium channels generated by the human alpha 1I subunit. J Biol Chem 275:16530-16535. https://doi.org/10.1074/jbc. C000090200
103. Moran Y, Zakon HH (2014) The evolution of the four subunits of voltage-gated calcium channels: ancient roots, increasing complexity, and multiple losses. Genome Biol Evol 6:2210-2217. https://doi.org/10.1093/gbe/evu177

104. Morino H, Matsuda Y, Muguruma K, Miyamoto R, Ohsawa R, Ohtake T, Otobe R, Watanabe M, Maruyama H, Hashimoto K, Kawakami H (2015) A mutation in the low voltage-gated calcium channel CACNA1G alters the physiological properties of the channel, causing spinocerebellar ataxia. Mol Brain 8:89. https:// doi.org/10.1186/s13041-015-0180-4

105. Murbartian J, Arias JM, Lee JH, Gomora JC, Perez-Reyes E (2002) Alternative splicing of the rat $\mathrm{Ca}(\mathrm{v}) 3.3 \mathrm{~T}$-type calcium channel gene produces variants with distinct functional properties(1). FEBS Lett 528:272-278. https://doi.org/10.1016/s00145793(02)03341-0

106. Najmabadi H, Hu H, Garshasbi M, Zemojtel T, Abedini SS, Chen W, Hosseini M, Behjati F, Haas S, Jamali P, Zecha A, Mohseni M, Puttmann L, Vahid LN, Jensen C, Moheb LA, Bienek M, Larti F, Mueller I, Weissmann R, Darvish H, Wrogemann K, Hadavi V, Lipkowitz B, Esmaeeli-Nieh S, Wieczorek D, Kariminejad R, Firouzabadi SG, Cohen M, Fattahi Z, Rost I, Mojahedi F, Hertzberg C, Dehghan A, Rajab A, Banavandi MJ, Hoffer J, Falah M, Musante L, Kalscheuer V, Ullmann R, Kuss AW, Tzschach A, Kahrizi K, Ropers HH (2011) Deep sequencing reveals 50 novel genes for recessive cognitive disorders. Nature 478: 57-63. https://doi.org/10.1038/nature10423

107. Nanba K, Blinder AR, Rege J, Hattangady NG, Else T, Liu CJ, Tomlins SA, Vats P, Kumar-Sinha C, Giordano TJ, Rainey WE (2020) Somatic CACNA1H mutation as a cause of aldosteroneproducing adenoma. Hypertension 75:645-649. https://doi.org/ 10.1161/HYPERTENSIONAHA.119.14349

108. Nanou E, Catterall WA (2018) Calcium channels, synaptic plasticity, and neuropsychiatric disease. Neuron 98:466-481. https:// doi.org/10.1016/j.neuron.2018.03.017

109. Ngo K, Aker M, Petty LE, Chen J, Cavalcanti F, Nelson AB, Hassin-Baer S, Geschwind MD, Perlman S, Italiano D, Lagana A, Cavallaro S, Coppola G, Below JE, Fogel BL (2018) Expanding the global prevalence of spinocerebellar ataxia type 42. Neurol Genet 4:e232. https://doi.org/10.1212/NXG. 0000000000000232

110. Nilius B, Hess P, Lansman JB, Tsien RW (1985) A novel type of cardiac calcium channel in ventricular cells. Nature 316:443-446. https://doi.org/10.1038/316443a0

111. Novara M, Baldelli P, Cavallari D, Carabelli V, Giancippoli A, Carbone E (2004) Exposure to cAMP and beta-adrenergic stimulation recruits $\mathrm{Ca}(\mathrm{V}) 3$ T-type channels in rat chromaffin cells through Epac cAMP-receptor proteins. J Physiol 558:433-449. https://doi.org/10.1113/jphysiol.2004.061184

112. Nowycky MC, Fox AP, Tsien RW (1985) Three types of neuronal calcium channel with different calcium agonist sensitivity. Nature 316:440-443. https://doi.org/10.1038/316440a0

113. Odgerel Z, Sonti S, Hernandez N, Park J, Ottman R, Louis ED, Clark LN (2019) Whole genome sequencing and rare variant analysis in essential tremor families. PLoS One 14:e0220512. https:// doi.org/10.1371/journal.pone.0220512

114. Orestes P, Osuru HP, McIntire WE, Jacus MO, Salajegheh R, Jagodic MM, Choe W, Lee J, Lee SS, Rose KE, Poiro N, Digruccio MR, Krishnan K, Covey DF, Lee JH, Barrett PQ, Jevtovic-Todorovic V, Todorovic SM (2013) Reversal of neuropathic pain in diabetes by targeting glycosylation of $\mathrm{Ca}(\mathrm{V}) 3.2 \mathrm{~T}$ type calcium channels. Diabetes 62:3828-3838. https://doi.org/ 10.2337/db13-0813

115. Park YG, Park HY, Lee CJ, Choi S, Jo S, Choi H, Kim YH, Shin HS, Llinas RR, Kim D (2010) Ca(V)3.1 is a tremor rhythm pacemaker in the inferior olive. Proc Natl Acad Sci U S A 107:1073110736. https://doi.org/10.1073/pnas.1002995107 
116. Pellegrini C, Lecci S, Luthi A, Astori S (2016) Suppression of sleep spindle rhythmogenesis in mice with deletion of $\mathrm{CaV} 3.2$ and CaV3.3 T-type Ca(2+) channels. Sleep 39:875-885. https:// doi.org/10.5665/sleep.5646

117. Perez-Reyes E (2003) Molecular physiology of low-voltageactivated t-type calcium channels. Physiol Rev 83:117-161. https://doi.org/10.1152/physrev.00018.2002

118. Perez-Reyes E, Lory P (2006) Molecular biology of T-type calcium channels. CNS Neurol Disord Drug Targets 5:605-609. https://doi.org/10.2174/187152706779025508

119. Perez-Reyes E, Cribbs LL, Daud A, Lacerda AE, Barclay J, Williamson MP, Fox M, Rees M, Lee JH (1998) Molecular characterization of a neuronal low-voltage-activated T-type calcium channel. Nature 391:896-900. https://doi.org/10.1038/36110

120. Perez-Rivas LG, Williams TA, Reincke M (2019) Inherited forms of primary hyperaldosteronism: new genes, new phenotypes and proposition of a new classification. Exp Clin Endocrinol Diabetes 127:93-99. https://doi.org/10.1055/a-0713-0629

121. Pinggera A, Lieb A, Benedetti B, Lampert M, Monteleone S, Liedl KR, Tuluc P, Striessnig J (2015) CACNA1D de novo mutations in autism spectrum disorders activate Cav1.3 L-type calcium channels. Biol Psychiatry 77:816-822. https://doi.org/10.1016/j. biopsych.2014.11.020

122. Powell KL, Cain SM, Ng C, Sirdesai S, David LS, Kyi M, Garcia E, Tyson JR, Reid CA, Bahlo M, Foote SJ, Snutch TP, O’Brien TJ (2009) A Cav3.2 T-type calcium channel point mutation has splice-variant-specific effects on function and segregates with seizure expression in a polygenic rat model of absence epilepsy. $\mathrm{J}$ Neurosci 29:371-380. https://doi.org/10.1523/JNEUROSCI. 5295-08.2009

123. Preiksaitiene E, Mannik K, Dirse V, Utkus A, Ciuladaite Z, Kasnauskiene J, Kurg A, Kucinskas V (2012) A novel de novo $1.8 \mathrm{Mb}$ microdeletion of $17 \mathrm{q} 21.33$ associated with intellectual disability and dysmorphic features. Eur J Med Genet 55:656659. https://doi.org/10.1016/j.ejmg.2012.07.008

124. Reimer EN, Walenda G, Seidel E, Scholl UI (2016) CACNA1H(M1549V) mutant calcium channel causes autonomous aldosterone production in HAC15 cells and is inhibited by mibefradil. Endocrinology 157:3016-3022. https://doi.org/ 10.1210/en.2016-1170

125. Rzhepetskyy Y, Lazniewska J, Blesneac I, Pamphlett R, Weiss N (2016) CACNA1H missense mutations associated with amyotrophic lateral sclerosis alter Cav3.2 T-type calcium channel activity and reticular thalamic neuron firing. Channels (Austin) 10:466477. https://doi.org/10.1080/19336950.2016.1204497

126. Rzhepetskyy Y, Lazniewska J, Proft J, Campiglio M, Flucher BE, Weiss N (2016) A Cav3.2/Stac1 molecular complex controls Ttype channel expression at the plasma membrane. Channels (Austin) 10:346-354. https://doi.org/10.1080/19336950.2016. 1186318

127. Sakkaki S, Gangarossa G, Lerat B, Francon D, Forichon L, Chemin J, Valjent E, Lerner-Natoli M, Lory P (2016) Blockade of T-type calcium channels prevents tonic-clonic seizures in a maximal electroshock seizure model. Neuropharmacology 101: 320-329. https://doi.org/10.1016/j.neuropharm.2015.09.032

128. Sanchez-Roige S, Fontanillas P, Elson SL, Gray JC, de Wit H, MacKillop J, Palmer AA (2019) Genome-wide association studies of impulsive personality traits (BIS-11 and UPPS-P) and drug experimentation in up to 22,861 adult research participants identify loci in the CACNA1I and CADM2 genes. J Neurosci 39: 2562-2572. https://doi.org/10.1523/JNEUROSCI.2662-18.2019

129. Schizophrenia Working Group of the Psychiatric Genomics C (2014) Biological insights from 108 schizophrenia-associated genetic loci. Nature 511:421-427. https://doi.org/10.1038/ nature 13595
130. Scholl UI, Stolting G, Nelson-Williams C, Vichot AA, Choi M, Loring E, Prasad ML, Goh G, Carling T, Juhlin CC, Quack I, Rump LC, Thiel A, Lande M, Frazier BG, Rasoulpour M, Bowlin DL, Sethna CB, Trachtman H, Fahlke C, Lifton RP (2015) Recurrent gain of function mutation in calcium channel CACNA1H causes early-onset hypertension with primary aldosteronism. Elife 4:e06315. https://doi.org/10.7554/eLife.06315

131. Seitter H, Koschak A (2018) Relevance of tissue specific subunit expression in channelopathies. Neuropharmacology 132:58-70. https://doi.org/10.1016/j.neuropharm.2017.06.029

132. Senatore A, Spafford JD (2012) Gene transcription and splicing of T-type channels are evolutionarily-conserved strategies for regulating channel expression and gating. PLoS One 7:e37409. https:// doi.org/10.1371/journal.pone.0037409

133. Shcheglovitov A, Vitko I, Bidaud I, Baumgart JP, NavarroGonzalez MF, Grayson TH, Lory P, Hill CE, Perez-Reyes E (2008) Alternative splicing within the I-II loop controls surface expression of T-type $\mathrm{Ca}(\mathrm{v}) 3.1$ calcium channels. FEBS Lett 582: 3765-3770. https://doi.org/10.1016/j.febslet.2008.10.013

134. Singh B, Monteil A, Bidaud I, Sugimoto Y, Suzuki T, Hamano S, Oguni H, Osawa M, Alonso ME, Delgado-Escueta AV, Inoue Y, Yasui-Furukori N, Kaneko S, Lory P, Yamakawa K (2007) Mutational analysis of CACNA1G in idiopathic generalized epilepsy. Mutation in brief \#962. Online. Hum Mutat 28:524-525. doi:https://doi.org/10.1002/humu.9491

135. Smith CL, Abdallah S, Wong YY, Le P, Harracksingh AN, Artinian L, Tamvacakis AN, Rehder V, Reese TS, Senatore A (2017) Evolutionary insights into T-type $\mathrm{Ca}(2+)$ channel structure, function, and ion selectivity from the Trichoplax adhaerens homologue. J Gen Physiol 149:483-510. https://doi.org/10.1085/ jgp.201611683

136. Snutch TP, Zamponi GW (2018) Recent advances in the development of T-type calcium channel blockers for pain intervention. $\mathrm{Br}$ J Pharmacol 175:2375-2383. https://doi.org/10.1111/bph.13906

137. Souza IA, Gandini MA, Wan MM, Zamponi GW (2016) Two heterozygous Cav3.2 channel mutations in a pediatric chronic pain patient: recording condition-dependent biophysical effects. Pflugers Arch 468:635-642. https://doi.org/10.1007/s00424-0151776-3

138. Souza IA, Gandini MA, Zhang FX, Mitchell WG, Matsumoto J, Lerner J, Pierson TM, Zamponi GW (2019) Pathogenic Cav3.2 channel mutation in a child with primary generalized epilepsy. Mol Brain 12:86. https://doi.org/10.1186/s13041-019-0509-5

139. Splawski I, Timothy KW, Sharpe LM, Decher N, Kumar P, Bloise R, Napolitano C, Schwartz PJ, Joseph RM, Condouris K, TagerFlusberg H, Priori SG, Sanguinetti MC, Keating MT (2004) $\mathrm{Ca}(\mathrm{V}) 1.2$ calcium channel dysfunction causes a multisystem disorder including arrhythmia and autism. Cell 119:19-31. https:// doi.org/10.1016/j.cell.2004.09.011

140. Splawski I, Yoo DS, Stotz SC, Cherry A, Clapham DE, Keating MT (2006) CACNA1H mutations in autism spectrum disorders. J Biol Chem 281:22085-22091. https://doi.org/10.1074/jbc. M603316200

141. Stringer RN, Jurkovicova-Tarabova B, Huang S, Haji-Ghassemi O, Idoux R, Liashenko A, Souza IA, Rzhepetskyy Y, Lacinova L, Van Petegem F, Zamponi GW, Pamphlett R, Weiss N (2020) A rare CACNA1H variant associated with amyotrophic lateral sclerosis causes complete loss of Cav3.2 T-type channel activity. Mol Brain 13:33. https://doi.org/10.1186/s13041-020-00577-6

142. Strom SP, Stone JL, Ten Bosch JR, Merriman B, Cantor RM, Geschwind DH, Nelson SF (2010) High-density SNP association study of the $17 \mathrm{q} 21$ chromosomal region linked to autism identifies CACNA1G as a novel candidate gene. Mol Psychiatry 15:9961005. https://doi.org/10.1038/mp.2009.41

143. Talavera K, Staes M, Janssens A, Droogmans G, Nilius B (2004) Mechanism of arachidonic acid modulation of the T-type $\mathrm{Ca} 2+$ 
channel alpha1G. J Gen Physiol 124:225-238. https://doi.org/10. 1085/jgp.200409050

144. Talley EM, Cribbs LL, Lee JH, Daud A, Perez-Reyes E, Bayliss DA (1999) Differential distribution of three members of a gene family encoding low voltage-activated (T-type) calcium channels. J Neurosci 19:1895-1911

145. Tatsuki F, Sunagawa GA, Shi S, Susaki EA, Yukinaga H, Perrin D, Sumiyama K, Ukai-Tadenuma M, Fujishima H, Ohno R, Tone D, Ode KL, Matsumoto K, Ueda HR (2016) Involvement of $\mathrm{Ca}(2+)$-dependent hyperpolarization in sleep duration in mammals. Neuron 90:70-85. https://doi.org/10.1016/j.neuron.2016. 02.032

146. Timic Stamenic T, Feseha S, Valdez R, Zhao W, Klawitter J, Todorovic SM (2019) Alterations in oscillatory behavior of central medial thalamic neurons demonstrate a key role of CaV3.1 isoform of T-channels during isoflurane-induced anesthesia. Cereb Cortex 29:4679-4696. https://doi.org/10.1093/cercor/ bhz002

147. Todorovic SM, Jevtovic-Todorovic V (2013) Neuropathic pain: role for presynaptic T-type channels in nociceptive signaling. Pflugers Arch 465:921-927. https://doi.org/10.1007/s00424-0121211-y

148. Todorovic SM, Jevtovic-Todorovic V (2014) Redox regulation of neuronal voltage-gated calcium channels. Antioxid Redox Signal 21:880-891. https://doi.org/10.1089/ars.2013.5610

149. Traboulsie A, Chemin J, Chevalier M, Quignard JF, Nargeot J, Lory P (2007) Subunit-specific modulation of T-type calcium channels by zinc. J Physiol 578:159-171. https://doi.org/10. 1113/jphysiol.2006.114496

150. Tsakiridou E, Bertollini L, de Curtis M, Avanzini G, Pape HC (1995) Selective increase in T-type calcium conductance of reticular thalamic neurons in a rat model of absence epilepsy. J Neurosci 15:3110-3117

151. van Loo KM, Schaub C, Pitsch J, Kulbida R, Opitz T, Ekstein D, Dalal A, Urbach H, Beck H, Yaari Y, Schoch S, Becker AJ (2015) Zinc regulates a key transcriptional pathway for epileptogenesis via metal-regulatory transcription factor 1 . Nat Commun 6:8688. https://doi.org/10.1038/ncomms 9688

152. Veselovskii NS, Fedulova SA (1983) 2 types of calcium channels in the somatic membrane of spinal ganglion neurons in the rat. Dokl Akad Nauk SSSR 268:747-750

153. Visa A, Shaikh S, Alza L, Herreros J, Canti C (2019) The hard-toclose window of T-type calcium channels. Trends Mol Med 25: 571-584. https://doi.org/10.1016/j.molmed.2019.03.001

154. Vitko I, Chen Y, Arias JM, Shen Y, Wu XR, Perez-Reyes E (2005) Functional characterization and neuronal modeling of the effects of childhood absence epilepsy variants of CACNA1H, a Ttype calcium channel. J Neurosci 25:4844-4855. https://doi.org/ 10.1523/JNEUROSCI.0847-05.2005

155. Vitko I, Bidaud I, Arias JM, Mezghrani A, Lory P, Perez-Reyes E (2007) The I-II loop controls plasma membrane expression and gating of $\mathrm{Ca}(\mathrm{v}) 3.2 \mathrm{~T}$-type $\mathrm{Ca} 2+$ channels: a paradigm for childhood absence epilepsy mutations. J Neurosci 27:322-330. https:// doi.org/10.1523/JNEUROSCI.1817-06.2007

156. Voisin T, Bourinet E, Lory P (2016) Genetic alteration of the metal/redox modulation of Cav3.2 T-type calcium channel reveals its role in neuronal excitability. J Physiol 594:3561-3574. https:// doi.org/10.1113/JP271925

157. Weiss N, Zamponi GW (2019) T-type channel druggability at a crossroads. ACS Chem Neurosci 10:1124-1126. https://doi.org/ 10.1021/acschemneuro.9b00031

158. Weiss N, Zamponi GW (2020) Genetic T-type calcium channelopathies. J Med Genet 57:1-10. https://doi.org/10.1136/ jmedgenet-2019-106163
159. Weiss N, Hameed S, Fernandez-Fernandez JM, Fablet K, Karmazinova M, Poillot C, Proft J, Chen L, Bidaud I, Monteil A, Huc-Brandt S, Lacinova L, Lory P, Zamponi GW, De Waard M (2012) A Ca(v)3.2/syntaxin-1A signaling complex controls Ttype channel activity and low-threshold exocytosis. J Biol Chem 287:2810-2818. https://doi.org/10.1074/jbc.M111.290882

160. Weiss N, Black SA, Bladen C, Chen L, Zamponi GW (2013) Surface expression and function of Cav3.2 T-type calcium channels are controlled by asparagine-linked glycosylation. Pflugers Arch 465:1159-1170. https://doi.org/10.1007/s00424-0131259-3

161. Welsby PJ, Wang H, Wolfe JT, Colbran RJ, Johnson ML, Barrett PQ (2003) A mechanism for the direct regulation of T-type calcium channels by $\mathrm{Ca} 2+/$ calmodulin-dependent kinase II. J Neurosci 23:10116-10121

162. Wolfe JT, Wang H, Howard J, Garrison JC, Barrett PQ (2003) Ttype calcium channel regulation by specific G-protein betagamma subunits. Nature 424:209-213. https://doi.org/10.1038/ nature 01772

163. Xie Y, Huang D, Wei L, Luo XJ (2018) Further evidence for the genetic association between CACNA1I and schizophrenia. Hereditas 155:16. https://doi.org/10.1186/s41065-017-0054-0

164. Xu W, Liu Y, Chen J, Guo Q, Liu K, Wen Z, Zhou Z, Song Z, Zhou J, He L, Yi Q, Shi Y (2018) Genetic risk between the CACNA1I gene and schizophrenia in Chinese Uygur population. Hereditas 155:5. https://doi.org/10.1186/s41065-017-0037-1

165. Yaari Y, Hamon B, Lux HD (1987) Development of two types of calcium channels in cultured mammalian hippocampal neurons. Science 235:680-682. https://doi.org/10.1126/science.2433765

166. Yunker AM, Sharp AH, Sundarraj S, Ranganathan V, Copeland TD, McEnery MW (2003) Immunological characterization of Ttype voltage-dependent calcium channel CaV3.1 (alpha 1G) and CaV3.3 (alpha 1I) isoforms reveal differences in their localization, expression, and neural development. Neuroscience 117:321-335. https://doi.org/10.1016/s0306-4522(02)00936-3

167. Zamponi GW, Lory P, Perez-Reyes E (2010) Role of voltagegated calcium channels in epilepsy. Pflugers Arch 460:395-403. https://doi.org/10.1007/s00424-009-0772-x

168. Zamponi GW, Striessnig J, Koschak A, Dolphin AC (2015) The physiology, pathology, and pharmacology of voltage-gated calcium channels and their future therapeutic potential. Pharmacol Rev 67:821-870. https://doi.org/10.1124/pr.114.009654

169. Zhang Y, Mori M, Burgess DL, Noebels JL (2002) Mutations in high-voltage-activated calcium channel genes stimulate lowvoltage-activated currents in mouse thalamic relay neurons. J Neurosci 22:6362-6371. https://doi.org/10.1523/JNEUROSCI. 22-15-06362.2002

170. Zhang Y, Jiang X, Snutch TP, Tao J (2013) Modulation of lowvoltage-activated T-type $\mathrm{Ca}(2)(+)$ channels. Biochim Biophys Acta 1828:1550-1559. https://doi.org/10.1016/j.bbamem.2012. 08.032

171. Zhao Y, Huang G, Wu Q, Wu K, Li R, Lei J, Pan X, Yan N (2019) Cryo-EM structures of apo and antagonist-bound human Cav3.1. Nature 576:492-497. https://doi.org/10.1038/s41586-019-1801-3

172. Zhong X, Liu JR, Kyle JW, Hanck DA, Agnew WS (2006) A profile of alternative RNA splicing and transcript variation of CACNA1H, a human T-channel gene candidate for idiopathic generalized epilepsies. Hum Mol Genet 15:1497-1512. https:// doi.org $/ 10.1093 / \mathrm{hmg} / \mathrm{ddl} 068$

Publisher's note Springer Nature remains neutral with regard to jurisdictional claims in published maps and institutional affiliations. 